\title{
KEMAMPUAN BERPIKIR KREATIF SISWA BERDASARKAN POLA ASUH ORANGTUA (Siswa Kelas VII DI SMP Negeri 8 Jakarta Pusat)
}

\author{
Intan Ratri Ranggawuni ${ }^{1}$ \\ Dra. Michiko Mamesah, M.Psi. ${ }^{2}$ \\ Happy Karlina Marjo, M.Pd., Kons. ${ }^{3}$
}

\begin{abstract}
Abstrak
Tujuan penelitian ini adalah untuk melihat gambaran kemampuan berpikir kreatif siswa. Tujuan lain penelitian ini, untuk mendapatkan perbedaan kemampuan berpikir kreatif siswa berdasarkan pola asuh yang diterapkan orangtua (otoriter, demokratis, atau permisif). Penelitian dilaksanakan pada siswa kelas VII SMP Negeri 8 Jakarta Pusat, teknik pengambilan sampel menggunakan teknik proportionate random sampling dengan tingkat kesalahan 5\%, sehingga sampel dalam penelitian ini berjumlah 100 siswa kelas VII SMP Negeri 8 Jakarta Pusat. Metode penelitian yang digunakan adalah metode komparatif. Pengumpulan data dilakukan menggunakan angket yang dikembangkan oleh peneliti mengenai kemampuan berpikir kreatif dan pola asuh orangtua.Hasil penelitian menunjukkan kemampuan berpikir kreatif siswa kelas VII SMP Negeri 8 Jakarta Pusat berada pada kategori sedang. Artinya siswa sudah cukup memiliki keluwesan pikiran, kepekaan terhadap masalah, orisinalitas, dan kefasihan akan gagasan. Selain itu, pengujian hipotesis menunjukkan bahwa nilai Asymp. Sig sebesar 0.844, yang berarti lebih besar dari nilai signifikansi a 0.05, sehingga Ho diterima, yaitu tidak terdapat perbedaan yang signifikan antara rata-rata kemampuan berpikir kreatif berdasarkan pola asuh otoriter, kemampuan berpikir kreatif berdasarkan pola asuh demokratis, dan kemampuan berpikir kreatif berdasarkan pola asuh permisif. Skor rata-rata kemampuan berpikir kreatif berdasarkan pola asuh permisif lebih besar dibandingkan skor rata-rata kemampuan berpikir kreatif demokratis dan otoriter.
\end{abstract}

Kata kunci: Kemampuan Berpikir Kreatif, Pola Asuh, Siswa SMP

\section{Pendahuluan}

Lingkungan keluarga merupakan lingkungan yang pertama dan utama bagi pendidikan anak.Proses pendidikan dalam keluarga disebut pendidikan informal. Selain melakukan pendidikan informal. Menurut Soelaeman (dalam Nurniati, 2007) bahwaorangtua mempunyai berbagai macam fungsi, salah satu diantaranya mengasuh putra-putrinya.Terdapat tiga pola pengasuhan yang umum digunakan oleh orangtua dan dikenal dalam masyarakat, yaitu pola asuh otoriter, demokratis dan permisif.

Bila dikaitkan dengan tipe pola asuh, kreativitas merupakan hasil konkrit pengasuhan yang disertai dengan terbentuknya kepribadian anak se-

\footnotetext{
Mahasiswa Jurusan Bimbingan dan Konseling FIP UNJ, intan.ratrii@gmail.com

2 Dosen Bimbingan dan Konseling FIP UNJ, michikomamesah@yahoo.com

3 Dosen Bimbingan dan Konseling FIP UNJ, happy.hanum2007@gmail.com
} 
jak usia tumbuh kembang. Hasil penelitian yang dilakukan oleh Hans Jellen dan Klaus Urban (dalam Rahman, 2012) menunjukkan bahwa dari 8 negara yang diteliti, kreativitas anak-anak Indonesia adalah yang terendah.Berikut ini adala rata-rata skor tes dari yang tertinggi sampai yang terendah: Filipina, Amerika Serikat, Inggris, Jerman, India, RRC, Kamerun, Zulu, dan terakhir Indonesia. Penyebab rendahnya kreativitas anak Indonesia adalah lingkungan yang kurang menunjang anak tersebut mengekspresikan kreativitas, khususnya pola pengasuhan keluarga dan sekolah.

Clark dalam teori kreativitas, menyatakan bahwa kreativitas dapat ditandai dengan empat ciri, salah satunya berpikir kreatif.Berpikir kreatif berpikir kreatif mengarah pada suatu pemecahan masalah serta lebih mengutamakan hasil yang baru meskipun tidak baru sama sekali. Berdasarkan studi pendahuluan menggunakan angket dan observasi yang dilakukan pada hari Rabu, 7 Mei 2013 terhadap 33 siswa kelas VIII-3 SMP Negeri 8 Jakarta Pusat, didapatkan hasil bahwa terdapat siswa yang suka menciptakan hal-hal baru karena orangtua mendukung; tidak suka dan tidak pernah menciptakan hal baru karena orang tua tidak mendukung dan cenderung mengabaikan; suka menciptakan hal-hal baru walaupun orangtua tidak mendukung; tidak suka menciptakan hal baru walaupun orangtua mendukung.

Adapun rumusan masalah dalam penelitian ini adalah: "Bagaimana gambaran perbedaan kemampuan berpikir kreatif siswa berdasarkan pola asuh orangtua" (siswa kelas VII di SMP Negeri 8 Jakarta Pusat?)". Sedangkan tujuan penelitian adalah untuk melihat gambaran kemampuan berpikir kreatif siswa. Tujuan lain dalam penelitian ini untuk mendapatkan perbedaan kemampuan berpikir kreatif siswa berdasarkan pola asuh yang diterapkan orang tua, baik itu pola asuh otoriter, demokratis dan permisif.

\section{Kajian Teori}

\section{a. Berpikir Kreatif}

Setiap siswa memiliki kemampuan dalam dirinya. Salah satu kemampuan yang dimiliki oleh setiap siswa adalah kreativitas. Guilford (dalam Leong, 2002) menyatakan kefasihan dan fleksibilitas berpikir, serta orisinalitas, kepekaan terhadap masalah, redefinitions dan elaborasi diklasifikasikan dalam kelompok kemampuan berpikir divergen. Guilford juga mengemukakan bahwa ada empat ciri utama dalam berpikir kreatif. Ciri-ciri tersebut adalah keluwesan, kepekaan terhadap masalah, orisinalitas, dan kefasihan akan gagasan.

Perkembangan kemampuan divergen atau berpikir kreatif biasanya melewati beberapa tahap. Wallas (dalam Semiawan, 2002) menjelaskan tentang tahap-tahap dalam proses berpikir kreatif berlangsung sebagai berikut yaitu preparation (persiapan), incubation (inkubasi), illumination (iluminasi), dan verification (verifikasi).

Berpikir kreatif akan tumbuh subur bila ditunjang oleh faktor personal dan situasional. Hurlock (1999) mengungkapkan ada beberapa faktor yang dapat mempengaruhi perkembangan berpikir kreatif diantaranya,(1) faktor internal, yaitu: (a) jenis kelamin, (b) status sosioekonomi, (c) urutan kelahiran, (d) inteligensi dan (2) faktor eksternal, yaitu:(a) waktu, (b) kesempatan untuk memperoleh pengetahuan,(c) cara mendidik anak, (d) dorongan, (e) hubungan orangtua - anak yang tidak posesif, (f) sarana, (g) lingkungan yang merangsang.

\section{b. Pola Asuh}

Setiap orangtua memiliki tanggung jawab kepada pendidikan anak-anaknya, tanggung jawab tersebut meliputi pengasuhan, memimpin arah pertumbuhan dan perkembangan anak. Pengasuhan yang dilakukan orangtua mempunyai gaya/cara yang berbeda, baik dalam mendidik atau pun mengarahkan anak untuk mencapai apa yang menjadi harapan keluarga, agar berbagai aspek kepribadian dapat berkembang secara berkesinambungan untuk mencapai kematangan/ kedewasaan diri.

Gaya atau cara diterapkan oleh orangtua dalam mendidik anak itulah yang dinamakan pola asuh. Menurut Baumrind, (1966) pola asuh orang tua adalah interaksi antara orang tua dengan anak yang meliputi apa dan bagaimana orangtua memperlakukan anaknya tersebut. Ketika menerapkan pola asuh kepada anak, orangtua biasanya memiliki kecenderungan pada pola asuh tertentu. Baumrind (dalam Santrock, 2003) menekankan tiga tipe pengasuhan, yaitu: (1) pola asuh authoritarian (otoriter), (2) pola asuh authoritative (demokratis/otoritatif), dan (3) 
pola asuh laissez-faire/ permissive (permisif).

1. Pola Asuh Otoriter (Authoritarian Parenting) Baumrind (dalam Papalia, 2007) mendefinisikan pola asuh otoriter: "authoritarian parents value control and unquestioning obedience."Orangtua otoriter juga menegakkan dan menganut paham kepatuhan mutlak, mereka menghargai pengawasan serta kepatuhan yang tidak dapat disangkal. Lebih lanjut Baumrind (dalam Santrock, 2003) mengatakan pengasuhan yang otoriter adalah: suatu gaya membatasi dan bersifat menghukum yang menuntut anak untuk mengikuti petunjuk/perintah-perintah orangtua, menghormati pekerjaan dan usaha. Orangtua yang bersifat otoriter membuat batasan-batasan tegas terhadap anak, tidak memberi peluang yang besar kepada anak untuk bericara/bermusyawarah, menghukum anak mereka karena bertetangan sikap dengan standar yang diterapkan orangtua, lebih mengendalikan dan kurang hangat.

Selain bersifat menghukum dan kurang hangat, orangtua dengan pola asuh otoriter juga memiliki standar tingkah laku. Hal ini didukung oleh Baumrind (dalam Papalia, 2007) yang menyatakan bahwa "They try to make children conform to set a standard of conduct and punish them arbitrarily and forcefully for violating it". "They are more detached and less warm than other parents."

2. Pola Asuh Demokratis (Authoritative Parenting) Pola asuh demokratis menurut terminologi Baumrind (dalam Papalia, 2007) yaitu "parenting style blending respect for a child's individuality with an effort to instill social values."Orangtua dengan tipe pola asuh demokratis juga sangat memperdulikan anak mereka namun juga sangat tegas dalam menegakkan nilai-nilai sosial.

Lebih lanjut Baumrind mengungkapkan bahwa "They have confidence in their ability to guide children. But they also respect children's independent decision. Interest, opinions, and personalities. They are loving, and accepting but also deman good behavior, are firm in maintaining standards, and willing to impose limited, judicious punishment wheen necessary, within the context of a warm, supportive relationship. They explain the reasoning behind their stands and encourage verbal give and take."
3. Pola Asuh Permisif (Permissive Parenting) Baumrind (dalam Papalia, 2007) menyatakan bahwa orangtua dengan pola asuh permisif adalah "parenting styleemphasizing self expression and self-regulation."Lebih lanjut Baumrind menyatakan bahwa "They make few demands and allow children to monitor their own activities as much as possible. When they do have to make rules, they explain the reasons for them. They consult with children about policy decisions and rarely punish. They are warm, noncontrolling, and undemanding."

Orangtua dengan tipe pola asuh permisif selalu membolehkan anak mereka melakukan apa pun, mereka menghargai ekspresi pribadi dan pengaturan secara mandiri yang berkanaan dengan diri sendiri. Mempertimbangkan diri mereka sebagai sumber daya, bukan sebagai contoh atau model untuk ditiru, tidak terlalu banyak menuntut keinginan dan memperbolehkan anak untuk memonitor kegiatan mereka pantau seluas-luasnya. Selain itu, orangtua dengan pola asuh permisif menerima tanpa syarat perasaan-perasaan apa saja yang diungkapkan anak.

\section{Metode Penelitian}

Penelitian dilakukan di SMP Negeri 8 Jakarta Pusat yang berlokasi di Jalan Pegangsaan Barat, No. 1, Jakarta Pusat pada bulan April hingga bulan Desember 2013.Metode yang digunakan dalam penelitian ini adalah metode penelitian komparatif.Penelitian dilakukan untuk membandingkan perbedaan fakta-fakta objek yang diteliti berdasarkan kerangka pemikiran tertentu yaitu perbedaan variabel kemampuan berpikir kreatif siswa berdasarkan variabel pola asuh orangtua (pola asuh otoriter, demokratis dan permisif).

Populasi dalam penelitian ini yaitu seluruh siswa kelas VII di SMP Negeri 8 Jakarta Pusat yang berjumlah 144 siswa.Sampel penelitian diambil secara acak dengan menggunakan teknik proportionate random sampling. Teknik proportionate random sampling digunakan untuk memperoleh sampel representative. Pengambilan subyek menurut Arikuto (2002) setiap wilayah ditentukan seimbang atau sebanding dengan banyaknya subyek dalam masingmasing wilayah. 
Peneliti mengambil sampel dari masing-masing kelompok sampel dengan tingkat kesalahan sebesar 5\% (sampel 95\%) dari 144 yaitu 100 siswa.Perhitungan masing-masing kelompok sampel adalah:

a. Siswa dengan pola asuh otoriter: 22 / 144 x 100 $=15.28=15$ siswa

b. Siswa dengan pola asuh demokratis: 104 / $144 \mathrm{x}$ $100=72$ siswa

c. Siswa dengan pola asuh permisif: 18 / 144 x 100

$=12.5=13$ siswa

Peneliti menggunakan angket tertutup dengan model penilaian Skala Likertuntuk memperoleh data yang diinginkan.Angket variabel kemampuan berpikir kreatif dan pola asuh orangtua disusun berdasarkan teori kemampuan berpikir kreatif dan pola asuh.

\section{Hasil Penelitian dan Pembahasan}

Kemampuan berpikir kreatif merupakan suatu kemampuan yang dimiliki oleh setiap orang.Kemampuan berpikir kreatif juga dipengaruhi oleh pola asuh yang diterapkan orangtua.Usia remaja merupakan usia yang tepat untuk perkembangan kemampuan berpikir kreatif, karena pada masa ini remaja sudah mampu melakukan berbagai kombinasi pikiran, dan tindakan baik yang logis maupun abstrak. Seorang yang memiliki kemampuan berpikir kreatif ciri keluwesan dalam berpikir, kepekaan terhadap masalah, orisinalitas, dan kefasihan akan gagasan.

Berdasarkan hasil analisis secara deskriptif, secara umum dapat dikatakan bahwa pola asuh demokratis paling banyak diterapkan oleh orangtua siswa sebanyak 72 siswa (72\%). Hal ini dapat dilihat dari frekuensi 100 responden kemampuan berpikir kreatif siswa berdasarkan pola asuh orangtua, pola asuh otoriter terdiri dari 15 siswa (15\%) dengan pola asuh otoriter, 72 siswa (72\%) dengan pola asuh demokratis, dan 13 siswa (13\%) dengan pola asuh permisif. Artinya, orangtua siswa kelas VII SMP Negeri 8 Jakarta dalam mendidik dan membimbing lebih mengutamakan nilai pribadi siswa yang diimbangi dengan nilai-nilai sosial.

Orangtua mendorong siswa untuk mandiri tetapi tetapi ada batasan, menghargai keputusan, minat, pendapat, kepribadian siswa, penuh cinta, konsisten, berkeinginan, mempunyai standar.Selain itu, orangtua menerima tetapi juga menuntut perilaku yang baik, menjatuhkan hukuman yang bijaksana, memiliki hubungan yang hangat dan mendukung, selalu memberikan penjelasan, serta saling memberi dan menerima masukan secara lisan.Namun, berdasarkan perhitungan statistik, justru kemampuan berpikir kreatif siswa berdasarkan pola asuh permisif memiliki skor rata-rata tertinggi dibandingkan demokratis dan otoriter.

Berdasarkan hasil pengujian hipotesis diketahui bahwa tidak terdapat perbedaan yang signifikan antara rata-rata kemampuan berpikir kreatif berdasarkan pola asuh otoriter, kemampuan berpikir kreatif berdasarkan pola asuh demokratis, dan kemampuan berpikir kreatif berdasarkan pola asuh permisif siswa kelas VII SMP Negeri 8 Jakarta. Tidak terdapat perbedaan juga terdapat pada penelitian Munjidah (2009) yang berjudul "Hubungan Antara Pola Asuh Orangtua Terhadap Tingkat Berpikir Kreatif Siswa SMAN 5 Malang" mendapatkan kesimpulan bahwa semakin tinggi orangtua menerapkan pola asuh pada siswa maka akan semakin rendah pula tingkat berpikir kreatif pada siswa.

Tidak terdapat perbedaan antara kemampuan berpikir kreatif berdasarkan pola asuh ototiter, demokratis dan permisif dapat dilihat dari kategori masing-masing kemampuan berpikir kreatif berdasarkan pola asuh.Ketiga kemampuan berpikir kreatif berdasarkan pola asuh, memiliki kategori sedang. Hal ini karena banyak orangtua yang menggunakan kombinasi dari beberapa pola asuh dan bukan hanya menggunakan satu pola asuh, meskipun terdapat satu pola asuh yang dominan dibandingkan yang lain. Orangtua yang bijaksana dapat menangkap pentingnya bersikap lebih permisif dalam situasi-situasi tertentu, lebih otoriter dalam situasi lain, dan lebih demokratis dalam situasi lainnya.Selain itu, ketiga kelompok kemampuan berpikir kreatif berdasarkan pola asuh, masing-masing berada pada tahap iluminasi.

Siswa yang berada pada tahap iluminasi sudah memahami permasalahan yang sedang di hadapi. Mereka mengumpulkan data-data dan informasi yang tersedia untuk mencoba merumuskan solusi pemecahan masalah.Setelah siswa merumuskan solusi pemecahan masalah, di tahap iluminasi mereka menemukan gagasan dan solusi pemecahan masalah yang sesuai dengan masalah yang sedang 
mereka alami.

Walaupun kemampuan berpikir kreatif berdasarkan pola asuh otoriter, demokratis, dan permisif berada pada kemampuan berpikir kreatif sedang, perhitungan statistik skor rata-rata kemampuan berpikir kreatif siswa berdasarkan pola asuh menunjukkan bahwa kemampuan berpikir kreatif siswa berdasarkan pola asuh permisif memiliki skor rata-rata 116,69, kemampuan berpikir kreatif siswa berdasarkan pola asuh otoriter sebesar 115 dan kemampuan berpikir kreatif siswa berdasarkan pola asuh demokratis sebesar 114,97. Dapat disimpulkan bahwa kemampuan berpikir kreatif siswa dengan pola asuh permisif lebih tinggi dibandingkan kemampuan berpikir kreatif siswa dengan pola asuh otoriter seperti gambar 1:

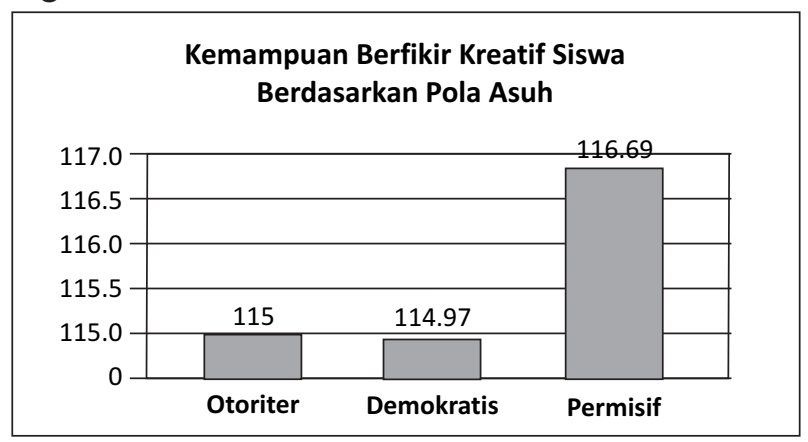

Gambar 1 Skor Rata-Rata Kemampuan Berpikir Kreatif Siswa Berdasarkan Pola Asuh

Persentase indikator tertinggi terdapat pada indikator kepekaan terhadap masalah, kemampuan berpikir kreatif siswa berdasarkan pola asuh otoriter sebesar 40\%, kemampuan berpikir kreatif siswa berdasarkan pola asuh demokratis sebesar $41 \%$ kemampuan berpikir kreatif siswa berdasarkan pola asuh permisif sebesar $42 \%$. Artinya, siswa sudah mampu untuk mengenali masalah dan mampu untuk menyelesaikan masalah. Persentase indikator terendah terdapat pada indikator kepekaan terhadap kefasihan akan gagasan. Siswa kurang mampu untuk memilih alternatif gagasan dan alternatif solusi dari suatu masalah.

Kemampuan berpikir kreatif siswa dengan pola asuh permisif memiliki skor rata-rata terbesar dan berada pada kategori sedang.Hal ini terjadi karena indikator kepekaan terhadap masalah serta keluwesan pikiran mendapatkan persentase tinggi.Selain itu, karakteristik orangtua dengan pola asuh per- misif mendukung perkembangan kemampuan berpikir kreatif. Orangtua dengan pola asuh permisif lebih menekankan ekspresi diri dan pengaturan diri siswa, sehingga siswa memiliki keluwesan pikiran dan mau mendengar serta menerima gagasan dari orang lain. Orangtua yang menerapkan pola asuh permisif, tidak banyak menuntut, membiarkan siswa untuk memantau kegiatan mereka sendiri membuat siswa menjadi peka terhadap masalah. Siswa yang diasuh dengan pola asuh permisif mampu mengenali masalah, dengan cara mencari fakta yang akan dibuktikan untuk mengatasi salah paham/salah konsepsi dari suatu masalah.

Tidak ada kontrol dan orangtua percaya untuk memberikan kebebasan kepada siswa, cenderung mempunyai siswa yang berpikir kreatif. Karena menurut Coleman dan Hammen, (dalam Rakhmat, 2007) seorang dengan kemampuan berpikir kreatif memiliki sikap yang bebas, otonom, percaya pada diri sendiri, tidak senang "digiring", ingin menampilkan diri semampunya dan semaunya serta tidak terlalu terikat dengan konvensi-konvensi sosial.

Orangtua dengan pola asuh permisif juga bersikap hangat.Kedekatan emosional yang hangat membuat siswa merasa diterima dan disayangi tetapi sewajarnya sehingga siswa tidak tergantung pada orangtua.Siswa yang memiliki kemampuan berpikir kreatif memperoleh banyak dorongan dari orangtua untuk melakukan hal-hal yang kreatif.

Skor rata-rata kemampuan berpikir kreatif berdasarkan pola asuh otoriter juga berada pada kategori sedang.Indikator keluwesan pikiran pada kemampuan berpikir kreatif berdasarkan pola asuh permisif memiliki persentase tertinggi. Sub-indikator menunjukkan mendengarkan gagasan orang lain dan menerima gagasan orang lain memiliki skor tertinggi. Siswa mau mendengarkan pendapat baik dari orangtua ataupun teman. Hal ini dikarenakan, orangtua dengan pola asuh otoriter, bersifat membatasi dan tidak memberikan peluang pada siswa untuk berbicara, sehingga siswa hanya mendengarkan apa yang dikemukakan oleh orangtua dan tidak terbiasa untuk mengemukakan pendapat di depan orang lain.

Persentase terendah terdapat pada indikator kefasihan akan gagasan. Siswa merasa kurang memiliki alternatif gagasan dan solusi masalah.Orangtua 
yang memiliki pola asuh otoriter membuat siswa menyesuaikan diri pada sekumpulan tingkah laku yang mereka ciptakan serta menetapkan batasan dan kendali yang tegas, sehingga siswa tidak fasih dalam menciptakan gagasan.

Begitu pula dengan skor rata-rata kemampuan berpikir kreatif siswa berdasarkan pola asuh demokratis, berada pada kategori sedang serta memiliki skor rata-rata terendah diantara kemampuan berpikir kreatif siswa berdasarkan pola asuh otoriter dan permisif.Perbedaan skor rata-rata yang tidak terlalu besar terjadi karena karakteristik antara pola asuh demokratis dengan pola asuh permisif tidak jauh berbeda.Pada pola asuh demokratis, orangtua bersikap menghargai keputusan, minat, pendapat, dan kemandirian siswa. Siswa yang berpikir kreatif biasanya memiliki orangtua yang menghormati mereka sebagai individu, percaya akan kemampuan siswa, dan menghargai keunikan siswa. Sehingga secara alamiah siswa mengembangkan kepercayaan diri untuk berani melakukan sesuatu yang orisinil.

Orangtua dengan pola asuh demokratis juga saling menerima dan memberi masukan secara lisan, yang membuat siswa mampu untuk mendengarkan gagasan orang lain secara baik. Karakteristik-karakteristik itulah yang mempengaruhi kemampuan berikir kreatif seorang siswa dengan pola asuh demokratis.

Berdasarkan hasil perhitungan menggunakan koefisien determinasi, didapatkan hasil R2 $=0,03$. Hal ini berarti faktor pola asuh orangtua dapat menjelaskan kemampuan berpikir kreatif siswa sebesar 3\%.Nilai tersebut dapat menggambarkan bahwa pola asuh orangtua memberikan pengaruh yang positif pada kemampuan berpikir kreatif siswa. Pengaruh yang diberikan pola asuh orangtua terhadap kemampuan berpikir kreatif tidak besar karena ada faktor lain yang juga turut mempengaruhi kemampuan berpikir kreatif siswa.

Faktor lain bisa berasal dari dalam diri siswa, ataupun luar diri siswa. Hal tersebut didukung oleh Hurlock (1999) yang mengungkapkan ada beberapa faktor yang dapat mempengaruhi perkembangan berpikir kreatif diantaranya: (1) faktor internal, yaitu: (1) jenis kelamin, anak laki-laki menunjukkan berpikir kreatif yang lebih besar daripada anak perempuan. Sedangkan responden penelitian lebih banyak berjenis kelamin perempuan dari pada yang berjenis kelamin laki-laki.(2) Status sosioekonomi, anak-anak yang berasal dari status sosioekonomi yang lebih tinggi cenderung lebih kreatif, dibandingkan anak dari status sosioekonomi lebih rendah. Responden dalam penelitian ini berada pada tingkat status sosioekonomi menengah ke bawah.

Selain faktor internal, Hurlock juga mengungkapkan ada faktor eksternal yyang mempengaruhi perkembangan kemampuan berpikir kreatif siswa, diantaranya: (3) cara mendidik anak, mendidik anak secara demokratis dan permisif di rumah atau di sekolah dapat meningkatkan kemampuan berpikir kreatif anak. Berdasarkan hasil penelitian, orangtua siswa lebih banyak mendidik anak secara demokratis dibandingkan permisif dan otoriter.(4) hubungan orangtua-siswa yang tidak posesif, orangtua yang tidak terlalu posesif terhadap anak mendorong anak untuk mandiri. Hal tersebut yang mendukung berkembangnya kemampuan berpikir kreatif. Hubungan orangtua-siswa yang tidak posesif merupakan bentuk dari pola asuh permisif, karena itu pada penelitian ini, kemampuan berpikir kreatif siswa berdasarkan pola asuh permisif memiliki nilai ratarata lebih tinggi dibandingkan demokratis dan permisif.

Guilford (dalam Munandar, 2009) juga mendukung pernyataan Hurlock, Guilord menyatakan bahwa menyatakan bahwa: "Faktor yang mempengaruhi pemikiran kreatif adalah faktor-faktor yang berhubungan dengan aptidute dan non-aptidute traits. Secara aptitude berfikir kreatif meliputi kelancaran, kelenturan dan orisinalitas.Ini ditunjukkan dengan kemampuan berfikir secara divergen.Sedangkan secara non-aptitude meliputi kepercayaan diri, keuletan, kemandirian dan lain sebagainya."

Berdasarkan penjelasan di atas diketahui bahwa faktor-faktor yang mempengaruhi kemampuan berpikir kreatif sebagai berikut: intelegensi, pengetahuan, pola pikir, kepribadian, motivasi, serta lingkungan.

\section{Kesimpulan dan Saran}

Setelah seluruh tahap penelitian dilaksanakan, didapatkan hasil penelitian dan analisis hasil penelitian, disimpulkan bahwa kemampuan berpikir kreatif berdasarkan pola asuh otoriter, demokratis dan 
permisif berada pada kategori sedang, artinya siswa sudah memiliki kemampuan berpikir kreatif, mampu membuktikan fakta, dan menemukan hambatan dari suatu permasalahan. Selain itu, hasil penelitian juga menunjukkan tidak terdapat perbedaan yang signifikan antara rata-rata kemampuan berpikir kreatif berdasarkan pola asuh otoriter, demokratis, dan permisif.Namun, kemampuan berpikir kreatif siswa dengan pola asuh permisif lebih tinggi dibandingkan kemampuan berpikir kreatif siswa otoriter dan demokratis.

Sebagai seorang guru, disarankan perlu menciptakan lingkungan yang nyaman dan merangsang di dalam kelas.Hendaknya tidak ada tekanan dan ketegangan. Guru BK juga harus memperhatikan strategi mengajar untuk meningkatkan kemampuan berpikir kreatif siswa, seperti: (1) pemberian penilaian tidak hanya dilakukan oleh guru, tetapi juga melibatkan siswa; (2) pemberian hadiah sebaiknya yang intangible, dan berkaitan dengan kegiatan yang sedang dilakukan; serta (3) memberikan kesempatan kepada siswa untuk memilih topik atau kegiatan belajar sampai batas tertentu.

\section{Daftar Pustaka}

Arikunto, Suharsimi. 2002. Prosedur Penelitian Suatu Pendekatan Praktik. Jakrta: PT Rineka Cipta.
Baumrind's, Diana. 1966. Prototypical Descriptions of 3 Parenting Styles. Developmental Psychology

Hurlock, B. Elizabeth. 1999. Perkembangan Anak Jilid 2. Jakarta: Erlangga.

Leong, Peter. 2002. I Can Cre8! Diterjemahkan oleh Gianto Widijanto.Jakarta: Prenhallindo.

Lestari, Barkah (Staf Pengajar FISE Universitas Negeri Jogjakarta). 2006. Upaya Orangtua Dalam Pengembangan Kreativitas Anak. Jurnal Ekonomi \& Pendidikan, Vol. 3, No. 1.

Munjidah.2009. Hubungan Antara Pola Asuh Orangtua Terhadap Tingkat Kreativitas Verbal Siswa SMAN 5 Malang, Skripsi (Tidak Diterbitkan). Malang: Fakultas Psikologi, Universitas Islam Negeri.

Nurniati. 2007. Peranan Orangtua Dan Guru Dalam Mengembangkan Kreativitas Siswa Sekolah Dasar. Karya ilmiah.

Papalia, Diane E., dkk. 2007. Human Development Tent Edition. New York: McGraw-Hill.

Rakhmat, Jalaluddin. 2007. Psikologi Komunikasi. Bandung: Rosda Karya.

Rahman, Risqi. 2012. Hubungan Antara Self-Concept Terhadap Matematika Dengan Kemampuan Berpikir Kreatif Matematika Siswa.Bandung: Invinity, Jurnal Ilmiah Program Studi Matematika STKIP Siliwangi Bandung, Vol. 1, No. 1.

Santrock. 2003. Adolescence: Perkembangan Remaja (6thed). Jakarta: Erlangga.

Semiawan, C, dkk. 2002. Dimensi Kreatif Dalam Filsafat Ilmu. Bandung: Rosdakarya. 